\title{
A multi-locus approach to barcoding in the Anopheles strodei subgroup (Diptera: Culicidae)
}

\author{
Brian Patrick Bourke ${ }^{1 *}$, Tatiane Porangaba Oliveira ${ }^{1}$, Lincoln Suesdek², Eduardo Sterlino Bergo ${ }^{3}$ \\ and Maria Anice Mureb Sallum ${ }^{1}$
}

\begin{abstract}
Background: The ability to successfully identify and incriminate pathogen vectors is fundamental to effective pathogen control and management. This task is confounded by the existence of cryptic species complexes. Molecular markers can offer a highly effective means of species identification in such complexes and are routinely employed in the study of medical entomology. Here we evaluate a multi-locus system for the identification of potential malaria vectors in the Anopheles strodei subgroup.

Methods: Larvae, pupae and adult mosquitoes $(n=61)$ from the An. strodei subgroup were collected from 21 localities in nine Brazilian states and sequenced for the COI, ITS2 and white gene. A Bayesian phylogenetic approach was used to describe the relationships in the Strodei Subgroup and the utility of COI and ITS2 barcodes was assessed using the neighbor joining tree and "best close match" approaches.

Results: Bayesian phylogenetic analysis of the COI, ITS2 and white gene found support for seven clades in the An. strodei subgroup. The COI and ITS2 barcodes were individually unsuccessful at resolving and identifying some species in the Subgroup. The COI barcode failed to resolve An. albertoi and An. strodei but successfully identified approximately 92\% of all species queries, while the ITS2 barcode failed to resolve An. arthuri and successfully identified approximately $60 \%$ of all species queries. A multi-locus COI-ITS2 barcode, however, resolved all species in a neighbor joining tree and successfully identified all species queries using the "best close match" approach.

Conclusions: Our study corroborates the existence of An. albertoi, An. CP Form and An. strodei in the An. strodei subgroup and identifies four species under An. arthuri informally named A-D herein. The use of a multi-locus barcode is proposed for species identification, which has potentially important utility for vector incrimination. Individuals previously found naturally infected with Plasmodium vivax in the southern Amazon basin and reported as An. strodei are likely to have been from An. arthuri C identified in this study.
\end{abstract}

Keywords: Culicidae, Anopheles, Strodei Subgroup, Identification, Barcode, COI, ITS2, White, Atlantic Forest, New species

\section{Background}

One of the most important goals of medical entomology is to develop approaches that effectively identify the roles of insect species in transmitting infectious pathogens. The incrimination of a pathogen vector requires demonstrating that the species feeds on humans, an association in time and space between the species and the occurrence of human infections, repeated isolation of the pathogen from the species, and the transmission of

\footnotetext{
* Correspondence: bpbourke@usp.br

1 Departamento de Epidemiologia, Faculdade de Saúde Pública, Universidade de São Paulo, São Paulo-SP, Brazil

Full list of author information is available at the end of the article
}

the pathogen by the species under controlled experimental conditions [1]. Fundamental to the process of incrimination is an ability to resolve and identify species effectively. However, many vector species are morphologically indistinguishable from close relatives yet they can exhibit a range of genetic, biological and morphological variation [2]. Such species form cryptic species complexes and their existence makes the task of vector incrimination more difficult. Molecular approaches are now routinely used to help resolve such complexes and have become essential tools in the study of medical entomology and infectious disease transmission.

\section{Biomed Central}


The phylogenetic analysis of species complexes employs markers with relatively high rates of substitution that are likely to track recently diverged species. A multi-locus approach can reconstruct more robust evolutionary relationships, discover previously unknown lineages in species and inform the search for latent morphological differences. Recently, DNA barcoding initiatives have proposed approaches that employ "sequence diversity in short, standardized gene regions to aid species identification and discovery in large assemblages of life" [3]. Various molecular markers [4-6] have been employed but it is cytochrome c oxidase I (COI) that has gained acceptance as the "gold standard" barcode for animals. The internal transcribed spacer region 2 (ITS2) has also been employed as a barcode region, primarily for plants but increasingly for animals [5]. The success of the barcoding approach is related to inter-specific variation exceeding intra-specific variation (the existence of the "barcoding gap"), and the analysis to date has generally been performed using clustering (neighbor joining tree monophyly) or pairwise genetic distances [7]. Recently diverged or incipient species, however, may be frequently misidentified due to incomplete lineage sorting of ancestral polymorphisms [8-10]. While barcoding is therefore a useful approach to determine minimum estimates of species numbers in cryptic species complexes although see [11], multi-locus and multi-data (genetic/morphological/ecological) approaches are likely to be more effective at elucidating the full extent of species diversity within these systems.

The current study focuses on species diversity within the Neotropical Strodei Subgroup of Anopheles (Nyssorhynchus) mosquitoes. This Subgroup is currently comprised of five species (Anopheles albertoi Unti, Anopheles arthuri Unti, Anopheles CP Form [12], Anopheles rondoni (Neiva and Pinto) and Anopheles strodei Root), which are distributed through much of Central and South America, from Panama to Argentina [13,14], although several additional taxa have been described and synonymized historically. Anopheles strodei was first described using morphological characters of the adult male, fourth-instar larvae and pupae from specimens from Juiz de Fora, Minas Gerais State, Brazil [15]. Later, An. albertoi, An. arthuri, An. artigasi Unti, and An. lloydi Unti were described based on egg characteristics and Anopheles ramosi Unti by the fourth-instar larvae [16,17]. The type localities of $A n$. albertoi, An. arthuri, An. artigasi, An. ramosi are all from Vale do Paraíba, São Paulo state, Brazil, whereas that of An. lloydi is an unspecified location in Panama. Further examination of $A n$. strodei based on adult female, larvae [13] and egg [18] morphology and patterns of the salivary polytene chromosome [19] showed high levels of polymorphism throughout its range and led Faran [13] to synonomize An. strodei, An. albertoi, An. arthuri, An. artigasi, An. lloydi, An. ramosi and An. strodei into a single species. A recent study of COI gene and white gene [12] sequences allowed the resurrection of $A n$. albertoi and $A n$. arthuri from synonomy with $A n$. strodei, and revealed an undescribed taxon, preliminarily named $A n$. CP Form.

Although Neotropical Anopheles species are known vectors of filariasis (Wuchereria bancrofti Cobbold [20]), arboviruses (Anopheles A Virus [21]) and malaria [22], the importance of the Strodei Subgroup in vectoring parasites is largely unknown. Anopheles strodei, however, has previously been found naturally infected with Plasmodium vivax Grassi \& Feletti in Ariquemes, Rondônia, in the Amazon region, [23] although it remains unknown whether this record refers to $A n$. strodei s.s. or another member of the Strodei Subgroup. The continental distribution of this complex confounds efforts to comprehensively describe species diversity and, ultimately, vectorial capacity. Our study seeks to provide a more complete understanding of species diversity and distribution in the Strodei Subgroup by performing a multi-locus DNA analysis of specimens collected from across Brazil. We will first resolve species relationships with a Bayesian approach using the COI, ITS2 and white gene. We will then test the utility of the COI barcode and the less frequently employed ITS2 barcode for species identification in the $A n$. strodei subgroup.

\section{Methods}

\section{Mosquito collection}

Collection localities and identity of the specimens included in this study can be found in Table 1. These specimens were either offspring of females caught in the field using a Shannon trap or larvae and pupae collected from immature habitats, which were then raised to adulthood. Species identification of all but two specimens was based on adult male genitalia, fourth-instar larval characteristics or scanning electron micrographs of the egg. Individuals from $A n$. arthuri displayed substantial variation in male genitalia and so were identified as An. arthuri sensu lato.

\section{DNA Extraction}

DNA was extracted from each specimen according to the animal tissue DNA extraction protocol provided by the QIAgen DNeasy ${ }^{\odot}$ Blood and Tissue Kit (QIAgen Ltd, Crawley, UK). All extractions were diluted to $200 \mu \mathrm{L}$ with the buffer provided and extraction solutions were retained for storage at $-80^{\circ} \mathrm{C}$ in the entomological frozen collection of the Faculdade de Saúde Pública, Universidade de São Paulo, Brazil.

\section{COl gene}

The gene was amplified using LCO- 1490 (5'-GGT CAA CAA ATC ATA AAG ATA TTG G-3') and HCO-2198 
Table 1 Sample information, including specimen numbers, species, localities, geographical coordinates, and Genbank accession numbers

\begin{tabular}{|c|c|c|c|c|c|c|c|}
\hline Specimen & Species & Locality (state) & Latitude & Longitude & COI GenBank accession no. & ITS2 GenBank accession no. & White GenBank accession no. \\
\hline MG07 124 & Anopheles albertoi & Frutal (Minas Gerais) & -20.025278 & -49.076500 & GU226678 & FJ178885 & GU226747 \\
\hline MG07 34 & Anopheles albertoi & Frutal (Minas Gerais) & -20.025278 & -49.076500 & GU226676 & FJ178889 & GU226742 \\
\hline$\overline{M G 07} 710$ & Anopheles albertoi & Frutal (Minas Gerais) & -20.025278 & -49.076500 & GU226677 & FJ178886-FJ178888 & GU226743-GU226746 \\
\hline CE12 11 & Anopheles arthuri B & Ubajara (Ceará) & -3.8867500 & -41.001250 & KC330250 & KC330268 & KC330325 \\
\hline CE12 46 & Anopheles arthuri B & Ubajara (Ceará) & -3.8867500 & -41.001250 & KC330251 & KC330269 & KC330326 \\
\hline CE17 152 & Anopheles arthuri B & Ubajara (Ceará) & -3.8442220 & -40.897778 & KC330253 & KC330270 & KC330328 \\
\hline CE17 51 & Anopheles arthuri B & Ubajara (Ceará) & -3.8442220 & -40.897778 & KC330252 & KC330271 & KC330327 \\
\hline CE20 104 & Anopheles arthuri B & São Benedito (Ceará) & -4.0964170 & -40.896361 & KC330254 & KC330272 & KC330329 \\
\hline CE20 24-3 & Anopheles arthuri B & São Benedito (Ceará) & -4.0964170 & -40.896361 & KC330255 & KC330273 & KC330330 \\
\hline GO7 13 & Anopheles arthuri A & Itarumã (Goiás) & -18.906128 & -51.024917 & KC330244 & KC330274 & KC330319 \\
\hline GO7 2102 & Anopheles arthuri A & Itarumã (Goiás) & -18.906128 & -51.024917 & KC330245 & KC330275-KC330277 & KC330320 \\
\hline GO7 3105 & Anopheles arthuri A & Itarumã (Goiás) & -18.906128 & -51.024917 & KC330246 & KC330278 & KC330321 \\
\hline GO7 6101 & Anopheles arthuri A & Itarumã (Goiás) & -18.906128 & -51.024917 & KC330247 & KC330279-KC330282 & KC330322 \\
\hline MG03 102 & Anopheles arthuri A & Frutal (Minas Gerais) & -19.981278 & -49.096028 & GU226679 & FJ178881-FJ178884 & GU226748 \\
\hline MG04 102 & Anopheles arthuri A & Frutal (Minas Gerais) & -19.988472 & -49.093361 & GU226680 & FJ178880 & GU226751 \\
\hline MG07 1100 & Anopheles arthuri A & Frutal (Minas Gerais) & -20.025278 & -49.076500 & GU226683 & FJ178879 & GU226752 \\
\hline MG07 10106 & Anopheles arthuri A & Frutal (Minas Gerais) & -20.025278 & -49.076500 & GU226684 & GU226712-GU226717 & GU226756 \\
\hline MG07 18100 & Anopheles arthuri A & Frutal (Minas Gerais) & -20.025278 & -49.076500 & GU226685 & GU226706 & GU226753-GU226755 \\
\hline MG07 202 & Anopheles arthuri A & Frutal (Minas Gerais) & -20.025278 & -49.076500 & GU226686 & GU226707-GU226711 & GU226750 \\
\hline MG07 63 & Anopheles arthuri A & Frutal (Minas Gerais) & -20.025278 & -49.076500 & GU226681 & GU226700-GU226705 & GU226749 \\
\hline$\overline{M G 24} 1$ & Anopheles arthuri A & Goianá (Minas Gerais) & -21.538836 & -43.200856 & GU226682 & GU226723-GU226725 & GU226757 \\
\hline MG32 4 & Anopheles arthuri A & Oliveira (Minas Gerais) & -20.746389 & -44.915278 & KC330257 & KC330283 & KC330332 \\
\hline MG33 112 & Anopheles arthuri A & Oliveira (Minas Gerais) & -20.745598 & -44.915613 & KC330258 & KC330284 & KC330340 \\
\hline MG33 126 & Anopheles arthuri A & Oliveira (Minas Gerais) & -20.745598 & -44.915613 & KC330259 & KC330285 & KC330334 \\
\hline MG33 137 & Anopheles arthuri D & Oliveira (Minas Gerais) & -20.508785 & -44.770600 & KC330256 & KC330286-KC330288 & KC330331 \\
\hline MG34 2 & Anopheles arthuri A & Oliveira (Minas Gerais) & -20.712500 & -44.974444 & KC330260 & KC330289 & KC330335 \\
\hline MG34 9 & Anopheles arthuri A & Oliveira (Minas Gerais) & -20.712500 & -44.974444 & KC330261 & KC330290 & KC330336 \\
\hline MG35 11 & Anopheles arthuri D & São Franscisco de Paula (Minas Gerais) & -20.754444 & -44.917222 & KC330262 & KC330291 & KC330338 \\
\hline MG44 142 & Anopheles arthuri A & Oliveira (Minas Gerais) & -20.768428 & -44.878209 & KC330263 & KC330292 & KC330339 \\
\hline RO29 18 & Anopheles arthuri C & Campo Novo de Rondônia (Rondônia) & -10.637639 & -65.499833 & KC330248 & KC330293 & KC330323 \\
\hline RO31 103 & Anopheles arthuri C & Campo Novo de Rondônia (Rondônia) & -10.637639 & -65.499833 & KC330249 & KC330294 & KC330324 \\
\hline$\overline{\mathrm{RO}} 1$ & Anopheles arthuri C & Monte Negro (Rondônia) & -10.268639 & -63.555389 & GU226681 & GU226727 & GU226759 \\
\hline RO8 104 & Anopheles arthuri C & Monte Negro (Rondônia) & -10.268639 & -63.555389 & GU226690 & GU226728 & GU226760 \\
\hline RO8 109 & Anopheles arthuri C & Monte Negro (Rondônia) & -10.268639 & -63.555389 & GU226689 & GU226729 & GU226761 \\
\hline
\end{tabular}


Table 1 Sample information, including specimen numbers, species, localities, geographical coordinates, and Genbank accession numbers (Continued)

\begin{tabular}{|c|c|c|c|c|c|c|c|}
\hline SP31 120 & Anopheles arthuri A & Inubia Paulista (São Paulo) & -21.681417 & -50.919889 & GU226687 & GU226699, GU226718-GU226722 & GU226758 \\
\hline MG15 11 & Anopheles CP Form & Coronel Pacheco (Minas Gerais) & -21.635819 & -43.319267 & JN413711 & KC330265 & KC330316 \\
\hline MG15 612 & Anopheles CP Form & Coronel Pacheco (Minas Gerais) & -21.635819 & -43.319267 & JN413712 & KC330266 & KC330317 \\
\hline MG1596 & Anopheles CP Form & Coronel Pacheco (Minas Gerais) & -21.635819 & -43.319267 & KC330243 & KC330267 & KC330318 \\
\hline$\overline{\text { PR21 } 110}$ & Anopheles CP Form & Foz do Iguaçu (Paraná) & -54.546528 & -25.454583 & GU226691 & FJ178890 & GU226762 \\
\hline BA23 3 & Anopheles strodei & São José da Vitória (Bahia) & -15.087060 & -39.341560 & KC330234 & KC330296 & KC330308 \\
\hline BA25 4 & Anopheles strodei & São José da Vitória (Bahia) & -15.090910 & -39.343700 & KC330235 & KC330297 & KC330309 \\
\hline ES09 1 & Anopheles strodei & Santa Teresa (Espírito Santo) & -19.916667 & -40.600000 & GU226664 & FJ178875 & GU226730 \\
\hline ES09 3 & Anopheles strodei & Santa Teresa (Espírito Santo) & -19.916667 & -40.600000 & GU226665 & FJ178874 & GU226731 \\
\hline$\overline{M G 27} 108$ & Anopheles strodei & Coronel Pacheco (Minas Gerais) & -21.587778 & -43.265833 & GU226669 & GU226693 & GU226735 \\
\hline MG30 102 & Anopheles strodei & Coronel Pacheco (Minas Gerais) & -21.587778 & -43.265834 & GU226670 & GU226694 & GU226736 \\
\hline MG3391 & Anopheles strodei & Oliveira (Minas Gerais) & -20.745598 & -44.915613 & KC330242 & KC330298 & KC330333 \\
\hline PR20 43 & Anopheles strodei & São Miguel do Iguaçu (Paraná) & -25.265361 & -54.309583 & KC330233 & KC330299 & KC330307 \\
\hline$\overline{P R 29} 233$ & Anopheles strodei & Foz do Iguaçu (Paraná) & -25.480556 & -54.586667 & GU226671 & GU226695 & GU226737 \\
\hline$\overline{R S 3798}$ & Anopheles strodei & Maquiné (Rio Grande do Sul) & -29.589556 & -50.262639 & KC330236 & KC330300 & KC330310 \\
\hline SP07 6 & Anopheles strodei & Buri (São Paulo) & -23.800000 & -48.566670 & GU226674 & FJ178878 & GU226740 \\
\hline SP104 181 & Anopheles strodei & Pindamonhangaba (São Paulo) & -22.960472 & -45.452083 & KC330240 & KC330301 & KC330314 \\
\hline SP105 1012 & Anopheles strodei & Pindamonhangaba (São Paulo) & -22.999333 & -45.495361 & KC330241 & KC330302 & KC330315 \\
\hline SP27 1 & Anopheles strodei & Lucélia (São Paulo) & -21.618861 & -50.940000 & GU226672 & GU226696 & GU226738 \\
\hline SP29 121 & Anopheles strodei & Lucélia (São Paulo) & -21.618861 & -50.940000 & GU226675 & GU226698 & GU226741 \\
\hline SP31 101 & Anopheles strodei & Inubia Paulista (São Paulo) & -21.681417 & -50.919889 & KC330232 & GU226697 & KC330306 \\
\hline SP56 33 & Anopheles strodei & Mairiporã (São Paulo) & -23.318889 & -46.586944 & KC330238 & KC330303 & KC330312 \\
\hline SP56 8 & Anopheles strodei & Mairiporã (São Paulo) & -23.318889 & -46.586944 & KC330237 & KC330304 & KC330311 \\
\hline SP66 151 & Anopheles strodei & Dourado (São Paulo) & -22.134694 & -48.391722 & KC330239 & KC330305 & KC330313 \\
\hline VP05 11A & Anopheles strodei & Pindamonhangaba (São Paulo) & -22.959750 & -45.452389 & GU226668 & FJ178877 & GU226734 \\
\hline VP06 52 & Anopheles strodei & Pindamonhangaba (São Paulo) & -22.959750 & -45.452389 & GU226667 & FJ178876 & GU226733 \\
\hline VP06 64 & Anopheles strodei & Pindamonhangaba (São Paulo) & -22.959750 & -45.452389 & GU226666 & GU226692 & GU226732 \\
\hline
\end{tabular}


(5'-TAA ACT TCA GGG TGA CCA AAA ATC A-3') primers [24]. The Polymerase Chain Reaction (PCR) was carried out in a $25-\mu \mathrm{L}$ aqueous reaction mixture containing $1 \mu \mathrm{L}$ of DNA extraction solution, 1X PCR buffer (Invitrogen, Carlsbad, CA, USA), $1.5 \mathrm{mM} \mathrm{MgCl} 2$ (Invitrogen), $1.25 \mu \mathrm{L}$ dimethly sulfoxide (Sigma, St. Louis, MO, USA), $0.1 \mu \mathrm{M}$ of each primer, $0.2 \mathrm{mM}$ each dNTP (Amresco, Solon, OH, USA) and 1.25 U Taq Platinum polymerase (Invitrogen). The reaction proceeded under the following temperature profile: $95^{\circ} \mathrm{C}$ for $2 \mathrm{~min}$, 35 cycles of $94^{\circ} \mathrm{C}$ for $1 \mathrm{~min}, 57^{\circ} \mathrm{C}$ for $1 \mathrm{~min}$ and $72^{\circ} \mathrm{C}$ for $1 \mathrm{~min}$ and a final extension at $72^{\circ} \mathrm{C}$ for $7 \mathrm{~min}$.

\section{ITS2 region}

This region was amplified using 5.8SF (5'-ATC ACT CGG CTC GTG GAT CG-3') and 28SR (5'-ATG CTT AAA TTT AGG GGG TAG TC-3') primers [25]. The PCR was carried out in a $25-\mu \mathrm{L}$ aqueous reaction mixture containing $1 \mu \mathrm{L}$ of DNA extraction solution, 1X PCR buffer (Invitrogen), $1.5 \mathrm{mM} \mathrm{MgCl} 2$ (Invitrogen), $1.25 \mu \mathrm{L}$ dimethyl sulfoxide (Sigma), $0.1 \mu \mathrm{M}$ of each primer, $0.2 \mathrm{mM}$ each dNTP (Amresco) and 1.25 U Taq Platinum polymerase (Invitrogen). The reaction proceeded under the following temperature profile: $94^{\circ} \mathrm{C}$ for $2 \mathrm{~min}, 34$ cycles of $94^{\circ} \mathrm{C}$ for $30 \mathrm{~s}, 57^{\circ} \mathrm{C}$ for $30 \mathrm{~s}$ and $72^{\circ} \mathrm{C}$ for $30 \mathrm{~s}$ and a final extension at $72^{\circ} \mathrm{C}$ for $10 \mathrm{~min}$. ITS2 amplicons that yielded ambiguous sequence chromatograms, which is suggestive of intragenomic variation, were purified using PEG precipitation (20\% polyethylene glycol $8,000 / 2.5 \mathrm{M} \mathrm{NaCl})$ and then cloned into pGem-T Easy Vector (Promega, Madison, WI).

\section{White gene}

This gene was amplified using WZ2E and WZ11 primers [26]. This amplification product then served as a template in a sequencing reaction using internal primers W1F (5'GAT CAA RAA GAT CTG YGA CTC GTT-3') and W2R (5'GCC ATC GAG ATG GAG GAG CTG-3'). Both PCRs were carried out in a $25-\mu \mathrm{L}$ aqueous reaction mixture containing $1 \mu \mathrm{l}$ DNA extraction solution, 1X PCR buffer (Invitrogen), $1.5 \mathrm{mM} \mathrm{MgCl} 2$ (Invitrogen), $2.5 \mu \mathrm{L}$ of dimethyl sulfoxide (Sigma), $2.0 \mu \mathrm{M}$ of each primer, $0.2 \mathrm{mM}$ each dNTP (Amresco) and 2.5 U Taq Platinum polymerase (Invitrogen). Both PCRs proceeded under the following temperature profile: $94^{\circ} \mathrm{C}$ for $5 \mathrm{~min}, 35$ cycles at $94^{\circ} \mathrm{C}$ for $30 \mathrm{~s}$, an annealing temperature of $50^{\circ} \mathrm{C}$ for $1 \mathrm{~min}$ and then $72^{\circ} \mathrm{C}$ for $2 \mathrm{~min}$ followed by a final extension at $72^{\circ} \mathrm{C}$ for $10 \mathrm{~min}$. Any white amplicons that yielded ambiguous sequence chromatograms were purified using PEG precipitation (20\% polyethylene glycol 8,000/2.5 M NaCl) and then cloned into pGem-T Easy Vector (Promega).

\section{Sequencing and sequence alignment}

Sequencing reactions were carried out in both directions using a Big Dye Terminator cycle sequencing kit v3.1
(Applied Biosystems, Foster City, CA, USA) and Applied Biosystems 3130 DNA Analyzer (Applied Biosystems). The $C O I$ and white gene sequences were aligned first by nucleotides using the Muscle algorithm [27] implemented in SeaView [28] and then by amino acid using TranslatorX [29].

The ITS2 sequences were annotated for the $5.8 \mathrm{~S}$ and $28 \mathrm{~S}$ ends using the ITS2 annotation tool [30] in the ITS2 Database [31]. ITS2 secondary structure was then predicted for each sequence using Mfold [32] and the sequence that gave the lowest minimum free energy, $\Delta G$, was used as a template to model the secondary structure of sequences using the Custom Modeling tool at the ITS2 Database. Sequences with secondary structures were then aligned and edited in 4 Sale $[33,34]$. Sequence edits were performed in Bioedit [35].

\section{Phylogenetic analysis}

Bayesian analysis was applied to COI, ITS2, white and combined gene sequence data using partitioning schemes to allow different partitions to have their own model characteristics (composition, rate matrix and among-site variation) and to allow for among-partition rate variation. Optimal evolutionary models were determined for each partition using the Akaike Information Criterion (AIC) in jModelTest 2 ([36]; Additional file 1). Optimal partition schemes were calculated using Bayes factors [37]. All Bayesian analyses were performed using MrBayes [38] on Bioportal [39] and each analysis consisted of two simultaneous runs, which were then repeated to provide confirmation of convergence of posterior probability distribution. While all ITS2 clones were included in the isolated gene analysis, only a single randomly selected ITS2 clone from each individual was included in the combined gene analysis.

For all Bayesian analyses, each run was 12 million generations long and the first six million were discarded as burn-in. The Metropolis-coupled Markov chain Monte Carlo strategy was used with six heated chains; adequate mixing was achieved by setting the chain temperature to between 0.1 and 0.2. Convergence of topology between the two runs was monitored using the average standard deviation of split frequencies - this index consistently fell to below 0.015 in the post-burn-in samples. Convergence was also monitored by noting the potential scale reduction factor values - these values were all approximately 1.0 in the post-burn-in samples. Consensus trees were constructed containing nodes with posterior probability support greater than $70 \%$. Trees were drawn using the R package APE [40].

\section{Barcoding analysis}

Individual pairwise Kimura-two-parameter (K2P) [41] distance matrices were constructed for COI, ITS2 and 
combined COI-ITS2 using APE. All ITS2 clones were included in this analysis, and these were combined with the corresponding $\mathrm{COI}$ sequence for each individual in the combined COI-ITS2 dataset. K2P Neighbor Joining (NJ) trees were constructed using Mega [42], with 10,000 bootstrap replicates. Minimum inter-specific and maximum intra-specific distances for each individual was calculated using the $\mathrm{R}$ package SPIDER [43]. The utility of these genes for barcoding was further tested using the "Best Close Match" (BCM) algorithm in TaxonDNA v1.7.8 [44]. This algorithm involves matching the query sequence to the most similar barcode within a specified species threshold. The query is then assigned the species name if it is within the 95th percentile of all intraspecific distances. The use of such a threshold offers advantages over arbitrary species identification thresholds as it is rigorously derived and can account for differences in mutation rate among loci and divergence among taxa.

\section{Results}

\section{Phylogenetic analysis}

A total of 61 individuals from the Strodei Subgroup were included in the analysis. After alignment these yielded 53 unique COI sequences of 638 base pairs in length, 49 unique ITS2 sequences of 432 base pairs in length, and

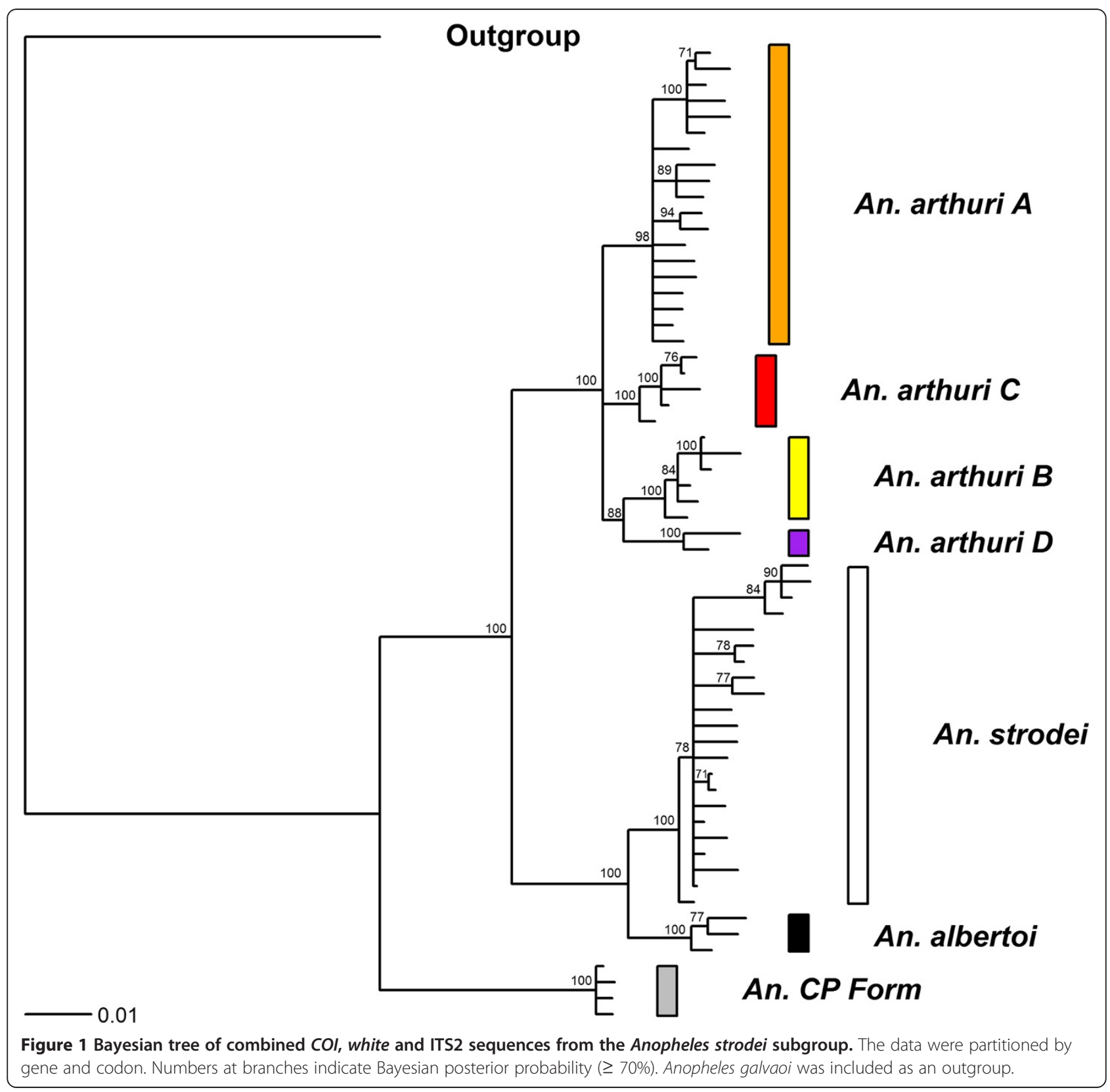


57 unique white sequences of 716 base pairs in length (including the intron of 109 base pairs in length). This gave a combined data set of 61 unique sequences of 1786 base pairs in length. Anopheles kompi Edwards (COI and white GenBank accession no. JF923715 and JN413731, respectively), Anopheles lutzii Cruz (COI and white GenBank accession no. JF923668 and JN392485, respectively), and Anopheles galvaoi Causey (COI, ITS2 and white GenBank accession numbers were KC330264, KC330295 and KC330337, respectively) were used as outgroup taxa. Anopheles kompi and An. lutzii could not be aligned at the ITS2 locus. The ITS2 locus was left un-partitioned for the Bayesian analysis, whereas, the best partition schemes for $\mathrm{COI}$ and white were those that partitioned by codon position with among-partition rate variation. The best partition scheme for the combined locus dataset was one that partitioned by locus and codon position.

Results of Bayesian analyses showed support for six clades in the combined gene tree (Figure 1). Anopheles $\mathrm{CP}$ Form was resolved from all other individuals across all gene trees. In the white gene (Figure 2), it was found as a sister to one of the outgroup taxa (An. galvaoi) and to a clade containing the remaining An. strodei subgroup. Anopheles arthuri s.l. individuals were resolved from others across all gene trees (Figures 1, 2, 3, and 4). There was no evidence for divergence among $A n$. arthuri s.l. individuals at ITS2 and white genes, and at

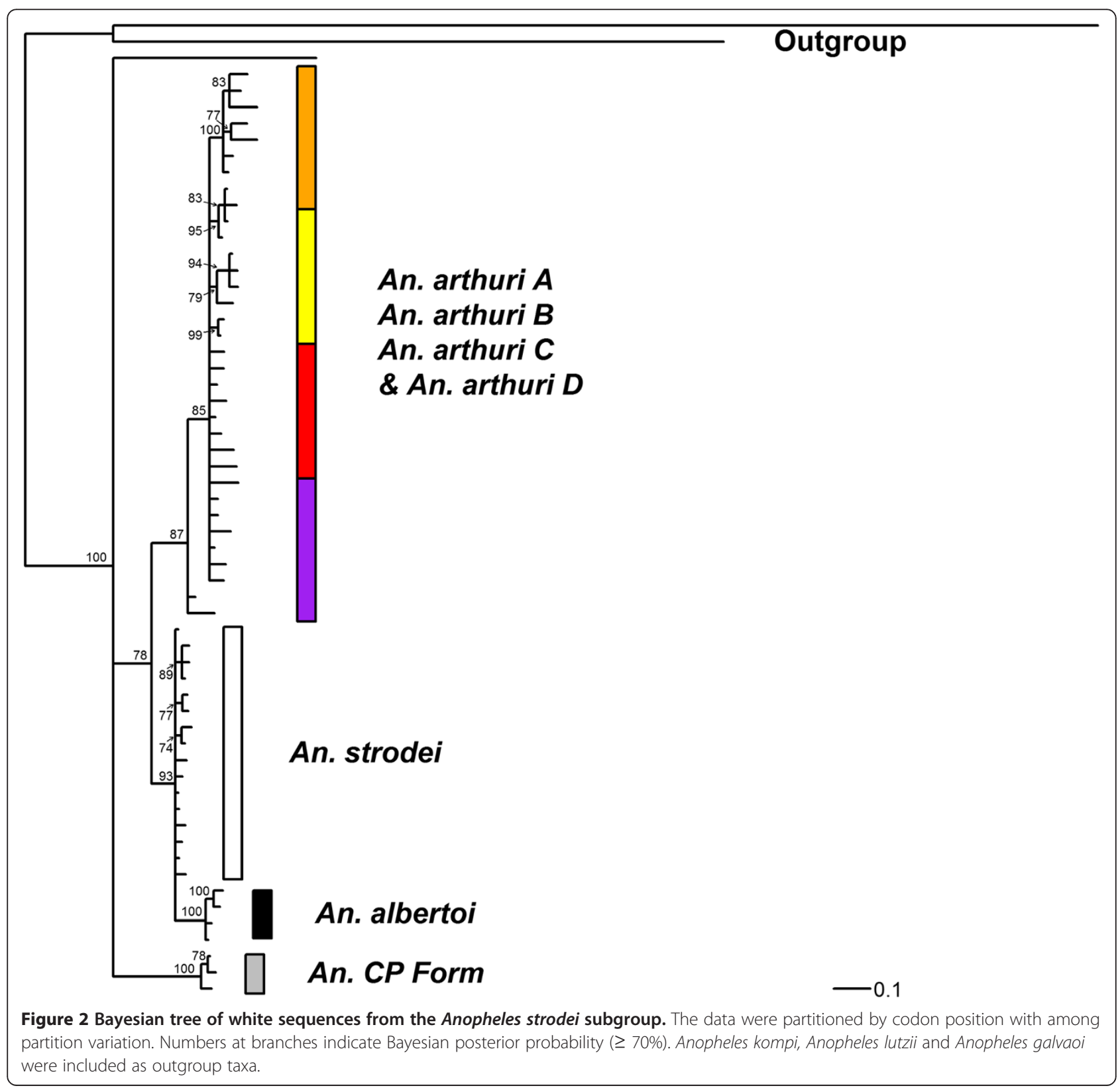




\section{Outgroup}
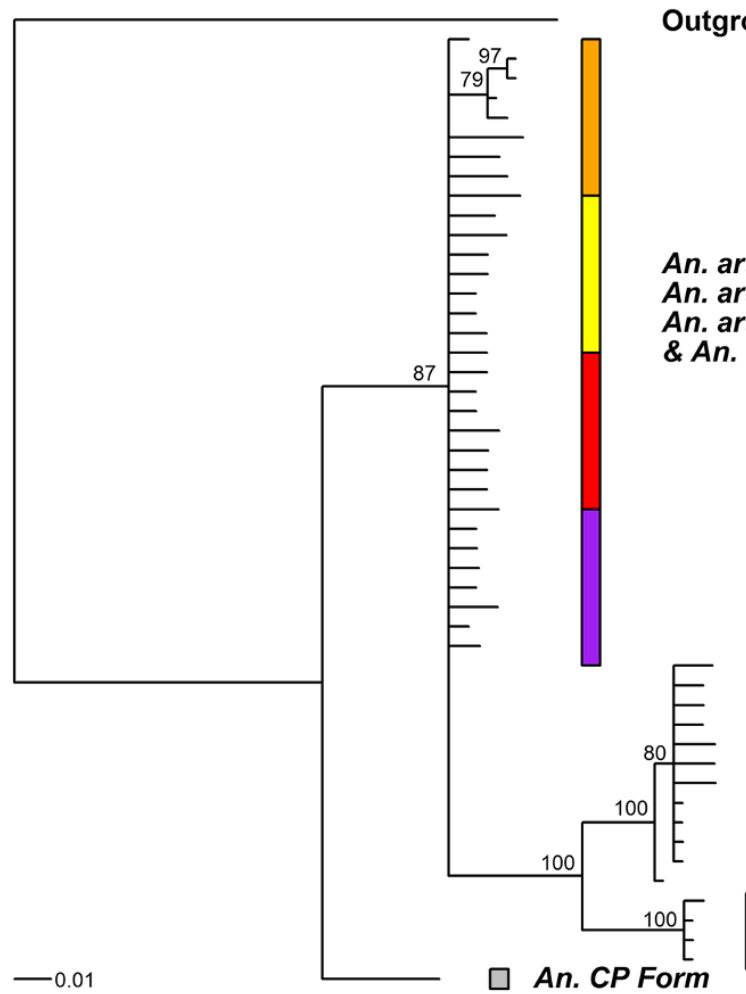

An. strodei

Figure 3 Bayesian tree of ITS2 sequences from the Anopheles strodei subgroup. Numbers at branches indicate Bayesian posterior probability $(\geq 70 \%)$. Anopheles galvaoi was included as an outgroup.

the ITS2 locus there was intra-genomic variation. Individuals that required cloning yielded between 2 and 6 clones and this intra-genomic variation $(0.26 \%-1.09 \%$ $\mathrm{K} 2 \mathrm{P})$ frequently exceeded inter-genomic variation. However, An. arthuri s.l. was resolved into four geographically meaningful clades in the COI gene tree (Figure 4). These four clades were found across Brazil (Figure 5), in the central/southern Brazilian states of Goiás, Minas Gerais and São Paulo (72\% Bayesian Posterior Probability, BPP; herein denoted An. arthuri A), the northern state of Ceará (91\% BPP; denoted An. arthuri B), the western Amazonian state of Rondônia (94\% BPP; denoted $A n$. arthuri $\mathrm{C}$ ) and southern Minas Gerais state (100\% BPP; denoted An. arthuri D), with the last being a sister to the Ceará clade (87\% BPP). Anopheles CP Form, $A n$. albertoi and $A n$. arthuri s.l. can be resolved from An. strodei individuals at ITS2, white and combined gene trees. However, $A n$. strodei and $A n$. albertoi form a single clade at the $C O I$ gene tree $(88 \% \mathrm{BPP})$.

\section{Barcoding analysis}

The Barcode NJ tree for COI (Figure 6) shows six clear groups. Individuals from An. arthuri s.l. can be found in the same four separate groups as found in the phylogenetic analysis. Figure 7 (a) shows a histogram of all intraand inter-specific $\mathrm{K} 2 \mathrm{P}$ COI differences among individuals and Figure 7 (b) shows a histogram of maximum intra- and minimum inter-specific K2P COI differences among individuals, when ordered into clades as defined by the phylogenetic analysis. Distances are measured in $0.001(0.1 \%)$ intervals. There are no barcoding gaps present in either histogram, and the intra- versus inter-specific distances shows a very high degree of overlap.

The Barcode NJ tree for ITS2 (Figure 8) shows four clear groupings - An. arthuri s.l., An. CP Form, $A n$. albertoi, and An. strodei. Figure 7 (c) and (d) show histograms of all intra- and inter- specific K2P ITS2 distance among individuals, and maximum intra- and minimum inter-specific K2P ITS2 distances among individuals, respectively, when ordered into clades as defined by the phylogenetic analysis. Again, there are no barcoding gaps present, and the intra- versus inter-specific distributions shows a very high degree of overlap.

The BCM analyses further explored the intra- and inter-specific distances in the COI (Additional file 2) and ITS2 (Additional file 3) barcodes. Threshold values for $95 \%$ of all intra-specific distances were determined for each barcode to evaluate whether a query (matching a test sequence to a reference sequence) had a close enough barcode match for identification. These were $1.92 \%$ for COI and $1.06 \%$ for ITS2. In total, $91.80 \%$ ( $\mathrm{n}=$ 


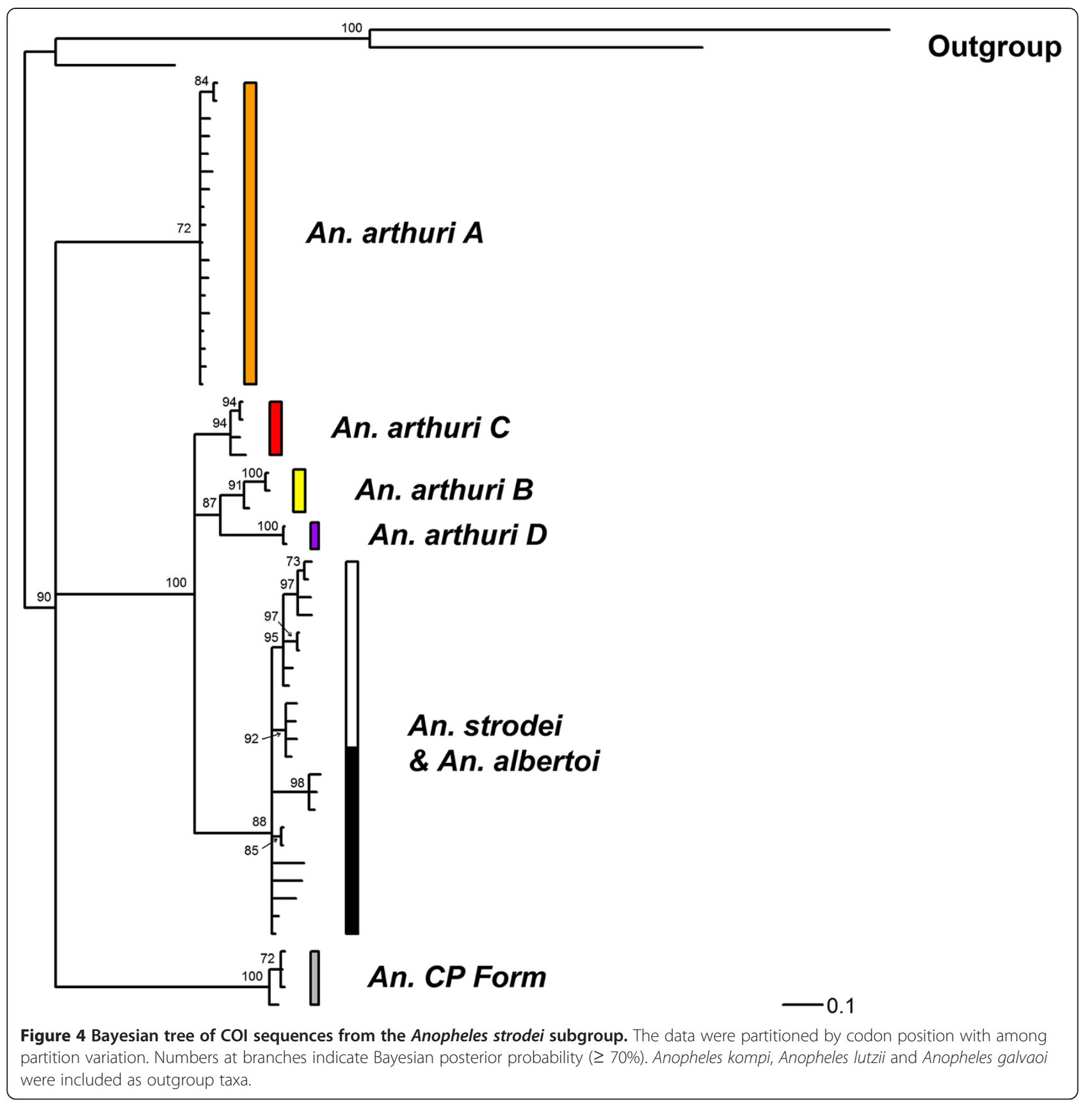

56) of queries were correctly identified by the COI barcode according to the BCM criteria. The COI barcode was highly effective at correctly identifying queries from $A n$. CP Form, An. arthuri A, An. arthuri B, $A n$. arthuri $\mathrm{C}$, and $A n$. arthuri D. All queries from these five species were successfully matched to their respective species groups. However, all three queries from $A n$. albertoi and two from $A n$. strodei were not successfully matched. The three $A n$. albertoi queries were incorrectly matched to $A n$. strodei, the first $A n$. strodei query was incorrectly matched to $A n$. albertoi and the second $A n$. strodei query was ambiguous as it was matched equally to both An. albertoi and An. strodei. The highest levels of intraspecific distances among all seven species were consistently from $A n$. albertoi and $A n$. strodei. Although intraspecific comparisons in the study ranged from $0 \%$ to $2.58 \%$, all of the intraspecific comparisons above $1.27 \%$ $(\mathrm{n}=232)$ were among $A n$. albertoi and An. strodei COI barcodes and intraspecific comparisons above $2.00 \%$ ( $\mathrm{n}=32$ ) were solely from An. strodei COI barcodes.

The BCM analysis for the ITS2 barcode found that only $59.55 \%(\mathrm{n}=53)$ of queries were correctly identified. All An. CP Form, An. albertoi and An. strodei queries were correctly matched to their respective species. 


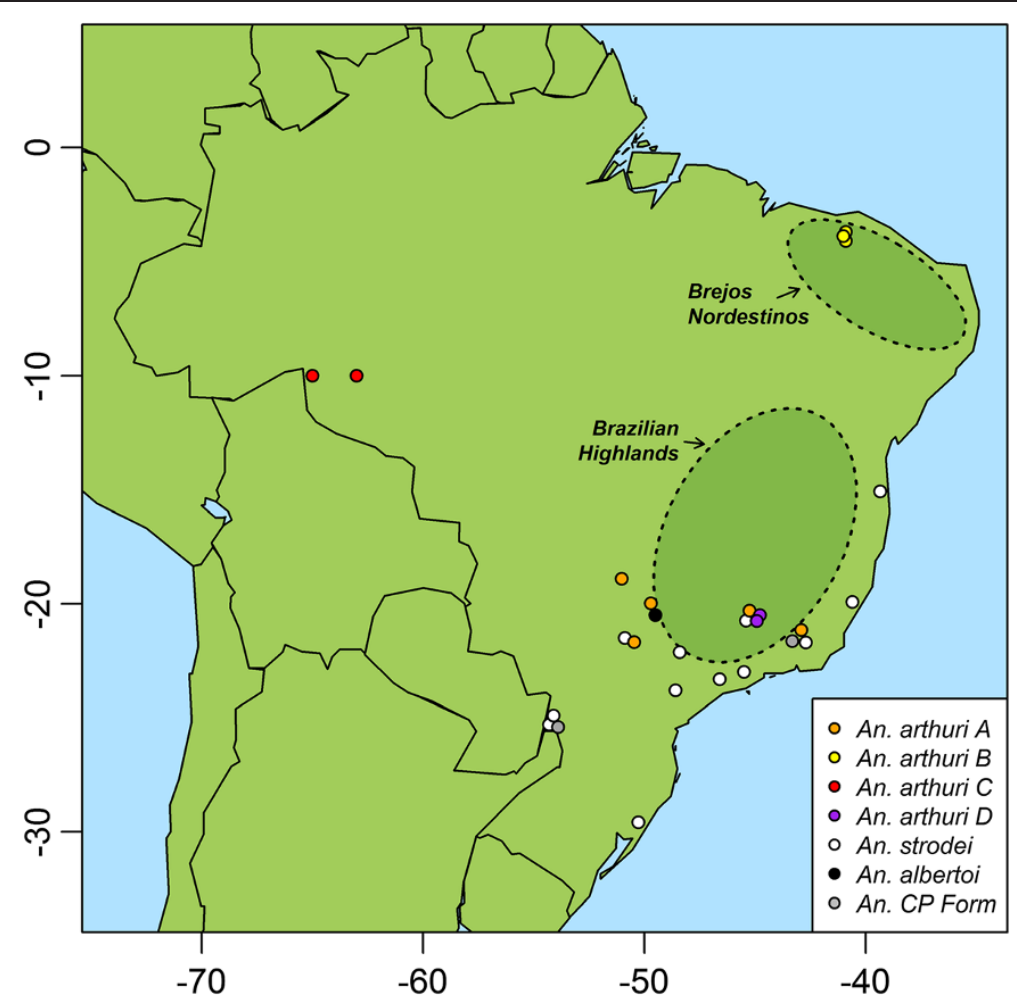

Figure 5 Sample distribution map. Geographical coordinates are taken from Table 1 and species are defined according to clades obtained from the Bayesian analysis.

However, $39.32 \%(n=35)$ of queries were ambiguous and $1.12 \%(\mathrm{n}=1)$ were incorrect and these came entirely from the $A n$. arthuri species.

The COI barcode, therefore, correctly identified all $A n$. $\mathrm{CP}$ Form, An. arthuri A, An. arthuri B, An. arthuri C, and $A n$. arthuri D, while the ITS2 barcode correctly identified all $A n$. CP Form, An. albertoi and $A n$. strodei individuals. A combined COI-ITS2 barcode was therefore tested first using a NJ tree (Figure 9) and then using the BCM analysis (with a 95\% intraspecific variation threshold of 1.11\%; Additional file 4). The results showed that all species could be resolved using the NJ tree and all BCM queries successfully identified $A n$. CP Form, An. arthuri, An. strodei, An. arthuri A, An. arthuri B, An. arthuri C, and $A n$. arthuri D. This was despite maintaining a small degree of overlap between intra- and inter-specific distances due to inflated levels of genetic variation in An. strodei (Figure 7 (e) and (f)).

\section{Discussion}

A recent study has added two additional species $(A n$. albertoi and $A n$. arthuri) to the An. strodei subgroup [12]. It also found support for a distinct morphological form, referred to as "CP Form", based on a single individual captured in the state of Paraná. In the current study we identified seven distinct lineages, of which three represented currently recognized species (An. strodei, An. arthuri s.s./An. arthuri A and $A n$. albertoi), and four are undescribed (An. arthuri B, An. arthuri C, An. arthuri D and $A n$. CP form).

The first important observation of the phylogeny is several incongruences among topologies generated from the DNA sequences. While ITS2 resolves $A n$. strodei and $A n$. albertoi, it fails to identify lineages within $A n$. arthuri s.l. The COI region, however, clearly resolves four $A n$. arthuri s.l. lineages, but fails to resolve $A n$. albertoi and $A n$. strodei. Differences between the gene genealogies and the species genealogy could be the result of incomplete lineage sorting or, in the case of ITS2, incomplete concerted evolution. In relation to incomplete lineage sorting, ancestral haplotypes can be retained in cases of recent speciation and/or large breeding populations, potentially resulting in the obscuring of phylogenetic signal among species. This process may explain the inability to resolve $A n$. strodei and $A n$. albertoi at the COI gene. Incomplete concerted evolution occurs when the rate of homogenization among copies in the ITS2 multi-gene family is insufficient to bring about fixation, potentially resulting in intra-genomic variation and shared haplotypes among closely related species. This process appears to be the cause of high levels of intragenomic variation in several species of Anopheles 


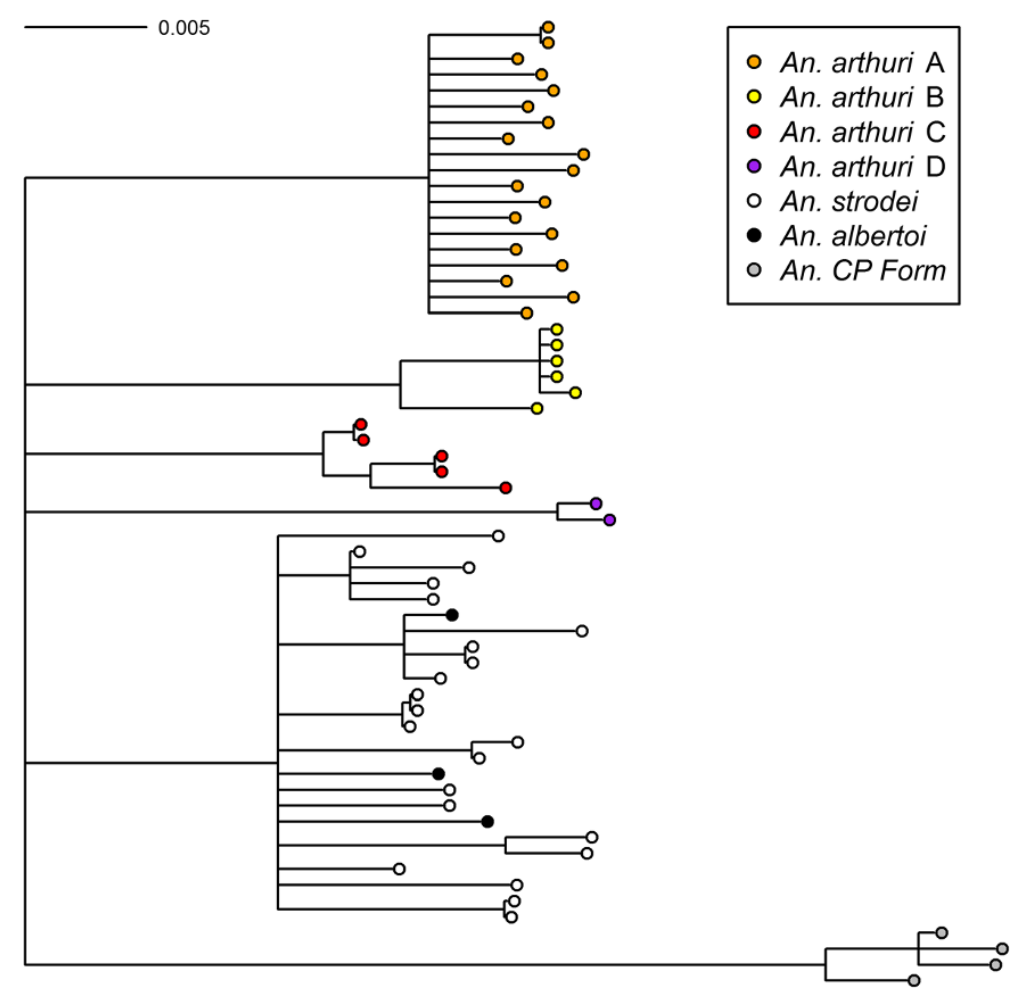

Figure 6 Bootstrapped neighbor joining tree of COI sequences from the Anopheles strodei subgroup. Constructed with Kimura's two parameter (K2P) distances and supported by 10,000 bootstrap replicates. All clades have greater than 70\% bootstrap support.

[45-49] and can potentially blur phylogenetic signal in some species, as appears to be the case among the $A n$. arthuri s.l. lineages in the current study.

Our phylogenetic analysis supports distinction of $A n$. albertoi and $A n$. arthuri s.l. as in previous work [12], but also further splits $A n$. arthuri s.l. into four distinct lineages (at the COI and combined gene tree). These lineages are geographically and ecologically distinct, and are herein referred to as An. arthuri A (from a central/ southern Brazilian region of Goiás, Minas Gerais, and São Paulo), An. arthuri B (from the northern Brazilian state of Ceará), An. arthuri C (from the Amazonian state of Rondônia) and An. arthuri D (from southern Minas Gerais). The An. arthuri A lineage can be found in the Interior Forest Subregion of the Atlantic Forest, where seasonal semi-deciduous forest dominates [50]. Individuals from this lineage were found on both the western and eastern slopes of the Brazilian Highlands (Figure 5). Three of these individuals (MG07_1_100, MG07_10_106 and MG07_18_100) were previously included in an assessment of egg morphology using scanning electron microscopy [12] and were found to be representative of the $A n$. arthuri type specimen. It is therefore likely that $A n$. arthuri A identified in this study is representative of $A n$. arthuri s.s. The An. arthuri B lineage is found in the Brejos Nordestinos Subregion of the Atlantic Forest.
This subregion marks the extreme northern reach of the Atlantic Forest and consists mainly of seasonal semideciduous forest or dense ombrophilous forest "islands" covering isolated plateaus, which are surrounded by arid Caatinga lowlands [50]. Whereas the Atlantic Forest was until recently largely contiguous, the forests of Brejos Nordestinos were isolated much earlier, during the climatic cycles of the Pleistocene [51]. Populations from these forest islands are therefore likely to be subject to greater levels of divergence via genetic drift and barriers to gene flow. The $A n$. arthuri $\mathrm{C}$ lineage is found in the southern reaches of the Amazonian river basin, to the north and west of the Parecis Mountains. We found no evidence for the presence of $A n$. strodei in this region and that it is likely that previous reports of $A n$. strodei found naturally infected with Plasmodium vivax in Rondônia [23] actually may refer to $A n$. arthuri C. The ranges of $A n$. arthuri A, $A n$. arthuri B and $A n$. arthuri C lineages are thus ecologically divergent, and appear to be highly allopatric (lineage sampling localities separated by more than $1600 \mathrm{~km}$ ). Two individuals also exist which were collected from Oliveira in the state of Minas Gerais with $C O I$ haplotypes that are significantly distinct from all others in the complex ( $>2.92 \%$ variation). These individuals were collected from a site in the Rio Pará Valley, near the headwaters of the São Francisco and the Paraná 


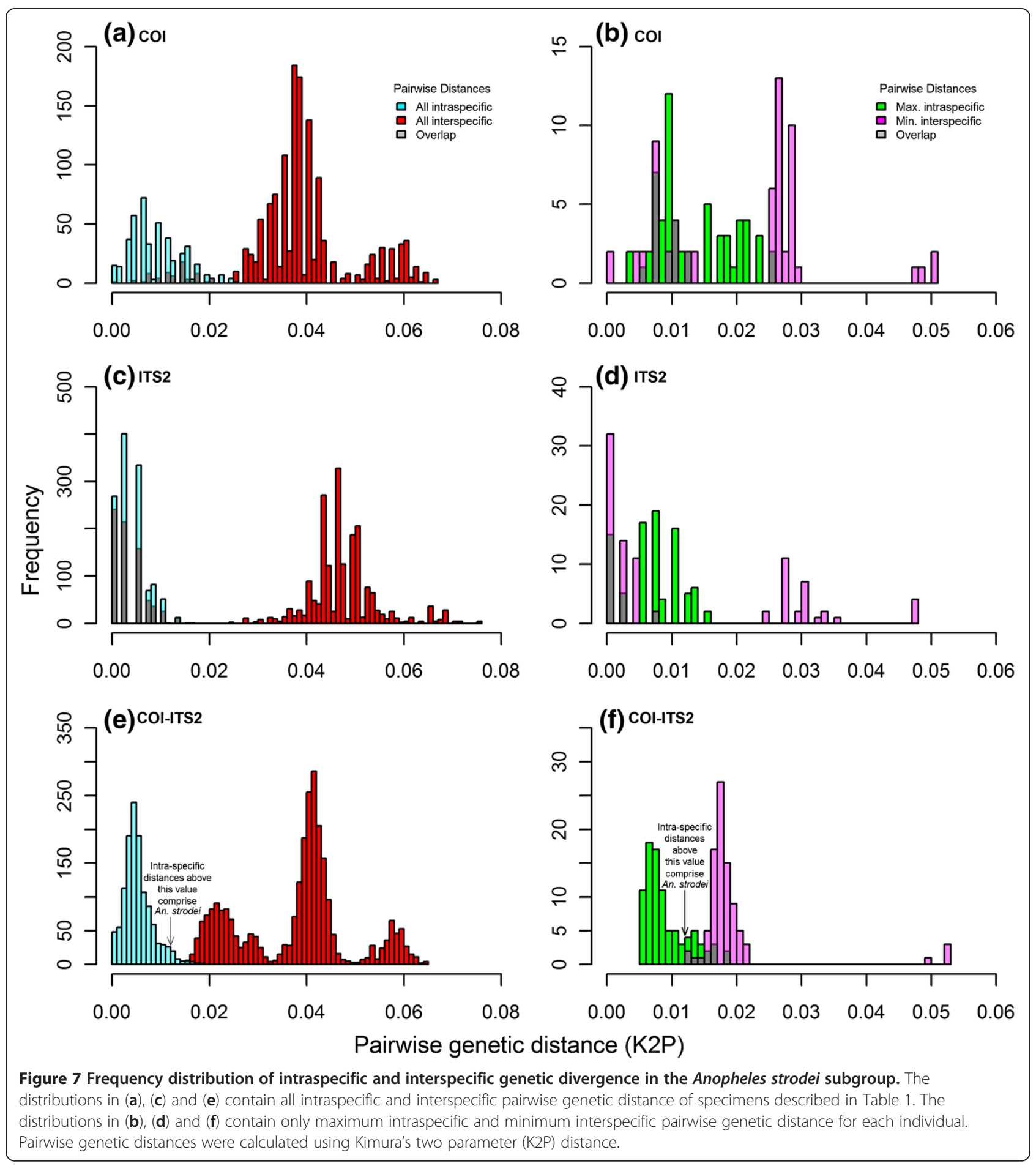

Rivers, at an altitude of approximately 1,000 meters, in a largely un-forested landscape at the interface of Brazil's Atlantic Forest and Cerrado eco-regions. They are found locally sympatric with $A n$. strodei and $A n$. arthuri A in this mountain valley but their absence from all other localities indicates that this species may be confined to mountainous areas in the Brazilian Highlands. Their distinction from other species may have been shaped by the considerable topographical structure in this region, serving as a barrier to gene flow and isolating them from other populations, and the varying selective pressures that potentially exist across the enclosed humid habitat of the Atlantic Forest and the open dry habitat of the Cerrado. These distinct Rio Pará Valley haplotypes are, 


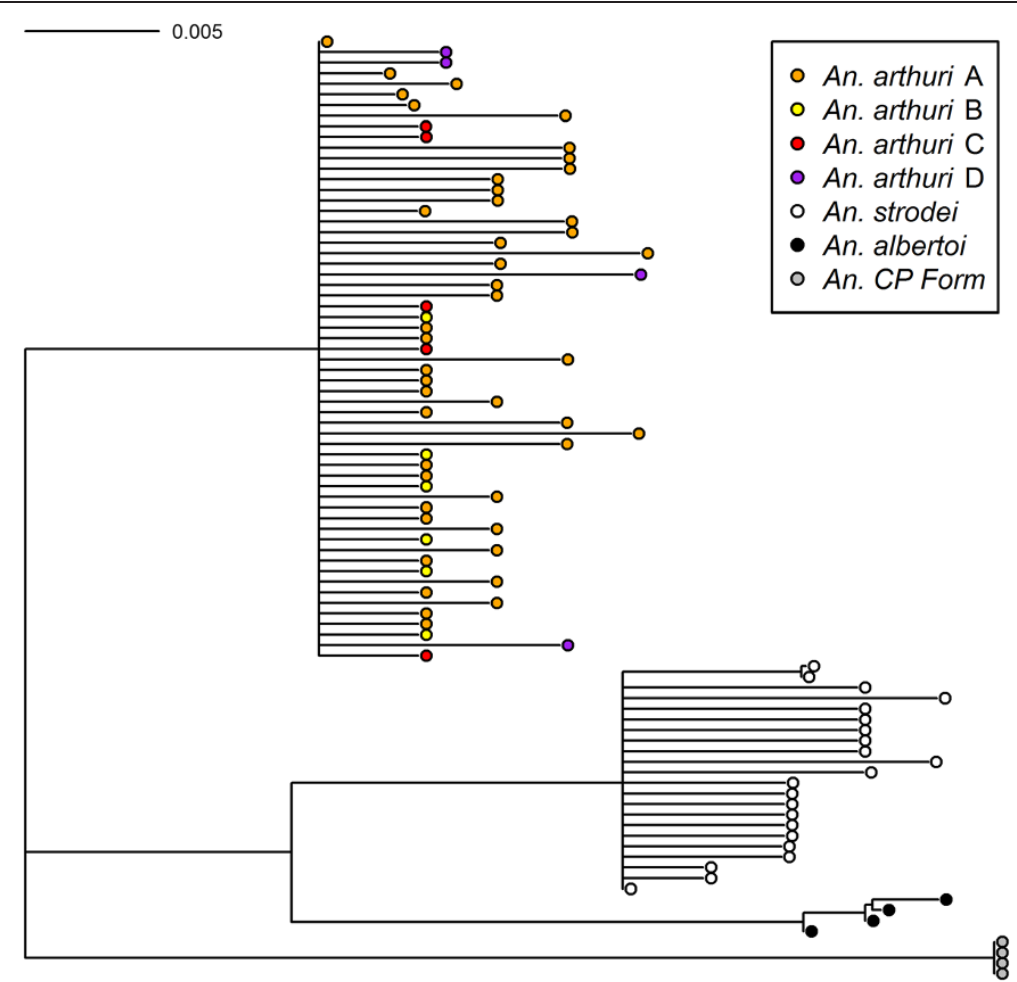

Figure 8 Bootstrapped neighbor joining tree of ITS2 sequences from the Anopheles strodei subgroup. Constructed with Kimura's two parameter (K2P) distances and supported by 10,000 bootstrap replicates. All clades have greater than 70\% bootstrap support.

therefore, tentatively identified as An. arthuri D, but clearly further sampling in more northerly localities in the São Francisco Valley is required to determine whether this represents a distinct species.

Previous analysis of the An. strodei subgroup found that An. albertoi can be distinguished morphologically, from its sister species by differences in the eggs (absence of a float) and male genitalia, and genetically, with the white and combined white-COI genes [12]. Using An. albertoi individuals from the study of Sallum et al. [12], we again differentiated this species from An. strodei and provide further genetic support for this lineage at the ITS2 gene. We have found the distribution of this species straddles the Brazilian Highlands, with individuals identified from the coastal forest of Serra do Mar in the state of São Paulo and the interior forest of the state of Minas Gerais, where it is found locally sympatric with An. arthuri A. The sampling associated with An. strodei is the most extensive among species in the study. Samples came from 14 different localities in six Brazilian states, some of which are separated by more than $2,000 \mathrm{~km}$. Although there was genetic and morphological support for this species, the substantial range of intra-specific distance at $C O I(0-2.58 \%)$ can be contrasted with intra-specific distances found in other species in this study (all less than 1.59\%) and the 1\% species identification threshold proposed in Ratnasingham and Hebert [3]. Comparable data, i.e. intra-specific pairwise distance ranges, from other studies of Anopheles species are scant, but higher intra-specific COI distances have been observed across a range of well supported species from the butterfly family Lycaenidae Leach [8]. Although the distribution of An. strodei haplotypes does not demonstrate geographic partitioning and there is no apparent variation in morphology or habitat, the levels of intra-specific variability present may be indicative of a high degree of cryptic population genetic structure. A comprehensive population genetic study, which includes more samples $(\mathrm{n}>20)$ from each of the 14 An. strodei localities detailed here, would help address this question and lead to a better understanding of the nature of genetic variation in this species.

The $A n$. CP Form individuals have previously been resolved from other species in the An. strodei subgroup based on differences observed in the male genitalia of a single individual collected in Foz do Iguaçu in the state of Paraná [12]. In the current study we have included additional individuals morphologically identified as $A n$. CP Form from Coronel Pacheco in the state of Minas Gerais and have found that all CP Form individuals can be resolved genetically across multiple genes. Although the $A n$. CP Form collection sites (Foz do Iguaçu, Paraná and Coronel Pacheco, Minas Gerais) are confined to the Interior Forest subregion of the Atlantic Forest, they are 


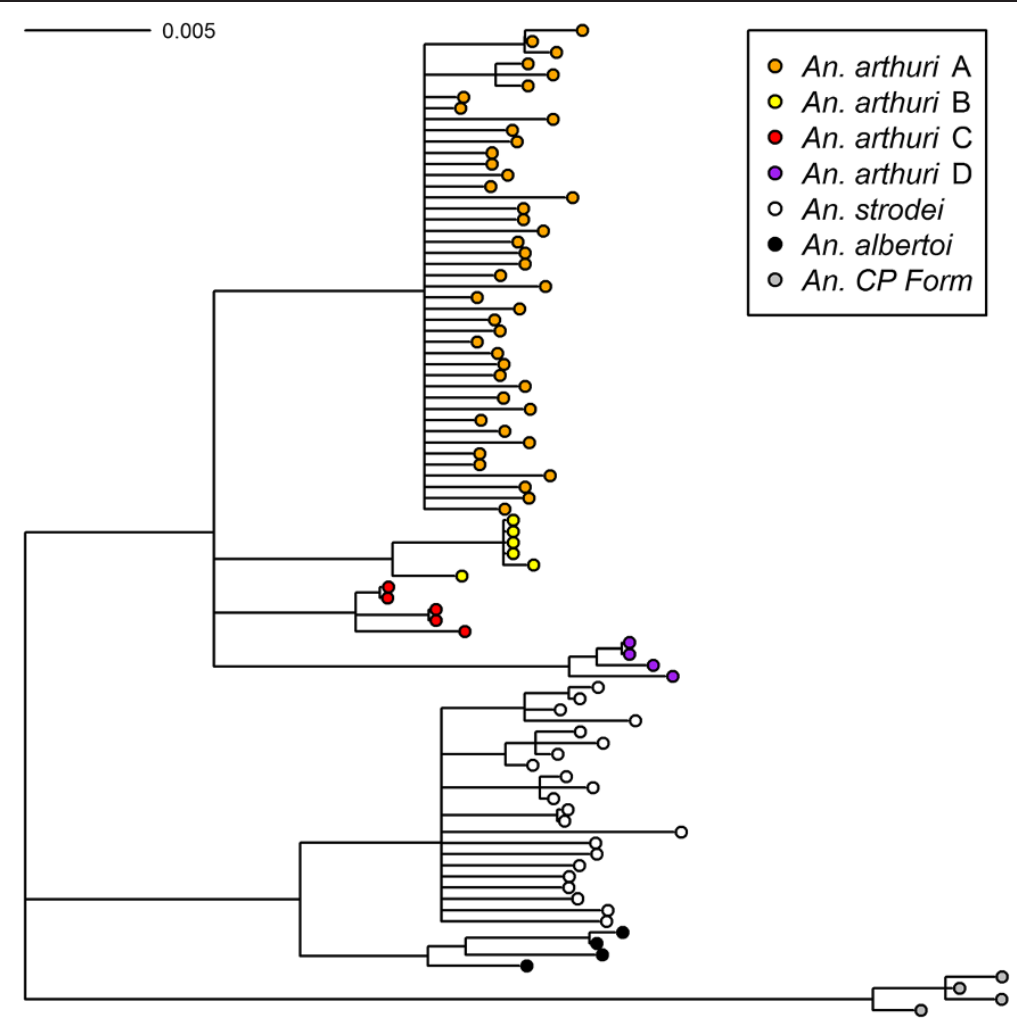

Figure 9 Bootstrapped neighbor joining tree of COI and ITS2 sequences from the Anopheles strodei subgroup. Constructed with Kimura's two parameter (K2P) distances and supported by 10,000 bootstrap replicates. All clades have greater than 70\% bootstrap support.

highly disparate, separated by more than $1,500 \mathrm{~km}$. This lineage's geographic distribution is further extended by its identification in the coastal state of Espírito Santo [52]. In addition, the lineage is found locally sympatric with other species from the An. strodei subgroup, namely $A n$. strodei in the west, and both $A n$. strodei and An. arthuri A in the east.

Generally, the most closely related species in the complex, i.e. within the An. strodei/An. albertoi clade and within the An. arthuri clade, are not found sympatrically, which may indicate allopatric speciation is the most important mode of speciation in this complex. However, the one exception to this pattern is species that are found in Rio Pará Valley. Here we find both An. arthuri $\mathrm{A}$ and $A n$. arthuri D (as well as An. strodei). It may be that the An. arthuri D clade represents a Brazilian Highland endemic as it has been unreported among more southerly and easterly localities, and that the southern limits of its range overlap with the northern limits of its sister species. However, further sampling through more northern localities of the São Francisco Valley and Brazilian Highlands is necessary to identify the breeding range of these species.

No single barcode was found to be effective at resolving all species identified from the phylogenetic analysis of the An. strodei subgroup. Neither COI nor ITS2 alone proved to be reliable as barcodes, largely because of their inability to resolve $A n$. albertoi/An. strodei and $A n$. arthuri species, respectively (as is evidenced by the considerable overlap between intra- and inter-specific differences). Many barcoding studies have demonstrated that the existence of substantial barcoding gaps permits effective species identification and discovery $[7,53,54]$. In closely related species, such as those found in species complexes, overlapping intra- and inter-specific variation are more likely and mainly due to processes such as incomplete lineage sorting [55]. However, although identification success generally declines with increasing overlap between intra- and inter-specific distances, studies have also shown that the existence of the barcoding gap does not predict the identification success of DNA barcoding [56,57]. In the current study we found that, although the COI and ITS2 barcodes do not have a barcoding gap and exhibit considerable overlap among the species identified through phylogenetic and morphological analysis, a combined COI-ITS2 barcode reduced the extent of overlap and provided a useful tool for species identification in the complex. An important advantage that the COI barcode has over the ITS2 barcode is the relative ease with which it can be aligned. The ITS2 
barcode is highly variable in relation to indels, and alignment of ITS2 sequences in Anopheles becomes extremely difficult in any other species other than close relatives. Therefore, while the COI-ITS2 barcode may provide an effective species tool in other anopheline species complexes, ITS2 sequence alignment is a mitigating factor for its use in more distantly related species.

Several studies have demonstrated that the extent and scale of intra-specific sampling and the inclusion of closely related species can have a significant impact on the global application of barcodes [58-60]. While intraspecific variation will tend to increase with increased geographical sampling, due to isolation by distance and geographic structure, inter-specific variation will tend to decrease due to the inclusion of more closely related allopatrically distributed species [61]. The current study has attempted to sample from a diverse range of localities from across the complexes' distribution (in nine Brazilian states) but most of the newly and tentatively identified species are clearly under-represented, numerically and geographically, particularly in the case of $A n$. albertoi $(\mathrm{n}=3)$ and $A n$. arthuri $\mathrm{D}(\mathrm{n}=2)$. Also, although $A n$. arthuri $\mathrm{C}$ is better represented in the study than the previous two species, the geographic distribution of these samples is quite limited versus potential $A n$. arthuri $\mathrm{C}$ breeding habitat in the Amazon basin. Recent studies have found that sample sizes used in DNA barcoding are generally low $[60,61]$ and that a sampling strategy of less than 20 individuals per species is unlikely to adequately represent intra-specific variation [60]. The shortcomings of the current study can therefore be addressed by future sampling in the geographically disparate localities, particularly within the Brazilian Highlands and the Amazon basin.

\section{Conclusion}

We identified seven possible species in the Anopheles strodei subgroup, three of which are reported here for the first time. The role of these as potential vectors of malaria is largely unknown but $A n$. strodei individuals previously found naturally infected with Plasmodium vivax in the Amazon region are likely to be $A n$. arthuri $\mathrm{C}$ identified herein. We found poor support for the use of a single barcode for species identification in this Subgroup. Although single barcodes may be useful to estimate minimum levels of speciosity in complexes, we found significant numbers of ambiguous or incorrect query matches when using this approach and would caution against their use for effective species identification in Anopheline species complexes. Instead, we propose a combined COI-ITS2 barcode as a potentially useful tool for species identification in the An. strodei complex, but recommend further sampling of intra-specific variation in order to more effectively assess the utility of this multi-locus barcode.

\section{Additional files}

\begin{abstract}
Additional file 1: Models used for locus and codon positions.
Additional file 2: Identification of species based on "best close
\end{abstract} match" and COI sequences.

Additional file 3: Identification of species based on "best close match" and ITS2 sequences.

Additional file 4: Identification of species based on "best close match" and combined COI-ITS2 sequences.

Competing interests

The authors declare that they have no competing interests.

\section{Authors' contributions}

MAMS and BPB conceived and designed the experiments. TMPO carried out the molecular laboratory work. ESB and MAMS did the field collections and identified the specimens. BPB performed the data analysis. BPB wrote the paper, with contributions from MAMS. All authors read and approved the final manuscript.

\section{Acknowledgements}

We are grateful to the Fundação de Amparo à Pesquisa do Estado de São Paulo (FAPESP, No. 2011/20397-7 to MAMS), Conselho Nacional de Desenvolvimento Científico e Tecnológico (CNPq, No. 301666/2011-3 to MAMS) and Coordenação de Aperfeiçoamento de Pessoal de Nível Superior (CAPES, No. 23038.005274/2011-24 to LSR) for financial support. We are also indebted to Denise Sant'Ana who kindly helped us with field collections.

\section{Author details}

${ }^{1}$ Departamento de Epidemiologia, Faculdade de Saúde Pública, Universidade de São Paulo, São Paulo-SP, Brazil. ² Laboratório de Parasitologia, Instituto Butantan, Avenida Vital Brasil, São Paulo-SP, Brazil. ${ }^{3}$ Superintendência de Controle de Endemias, Secretaria de Estado da Saúde de São Paulo, Araraquara-SP, Brazil.

Received: 20 November 2012 Accepted: 14 April 2013 Published: 19 April 2013

\section{References}

1. Barnett HC: The transmission of western equine encephalitis virus by the mosquito Culex tarsalis Coq. Am J Trop Med Hyg 1956, 5:86-98.

2. Rosa-Freitas MG, Lourenço-de-Oliveira R, de Carvalho-Pinto CJ, FloresMendoza C, Silva-Do-Nascimento TF: Anopheline species complexes in Brazil. Current knowledge of those related to malaria transmission. Mem Inst Oswaldo Cruz 1998, 93:651-655.

3. Ratnasingham S, Hebert PDN: BOLD: The Barcode of Life Data System (www.barcodinglife.org). Mol Ecol Notes 2007, 7:355-364.

4. Hebert PD, Cywinska A, Ball SL, deWaard JR: Biological identifications through DNA barcodes. Proc R Soc Lond B 2003, 270:313-321.

5. Yao H, Song J, Liu C, Luo K, Han J, Li Y, Pang X, Xu H, Zhu Y, Xiao P, Chen S: Use of ITS2 Region as the Universal DNA Barcode for Plants and Animals. PLoS One 2010, 5(10):e13102.

6. Dai QY, Gao Q, Wu CS, Chesters D, Zhu CD, Zhang AB: Phylogenetic reconstruction and DNA barcoding for closely related pine moth species (Dendrolimus) in China with multiple gene markers. PLOS One 2012, 7(4):e32544.

7. Hebert PD, Stoeckle MY, Zemlak TS, Francis CM: Identification of birds through DNA barcodes. PLOS Biol 2004, 2:e312.

8. Wiemers M Fiedler K: Does the DNA barcoding gap exist? - A case study in blue butterflies (Lepidoptera: Lycaenidae). Front Zool 2007, 4:8.

9. Hickerson MJ, Meyer CP, Moritz C: DNA barcoding will often fail to discover new animal species over broad parameter space. Syst Biol 2006, 55:729-739.

10. Hebert PD, Penton EH, Burns JM, Janzen DH, Hallwachs W: Ten species in one: DNA barcoding reveals cryptic species in the neotropical skipper butterfly Astraptes fulgerator. Proc Natl Acad Sci USA 2004, 101:14812-14817.

11. Song H, Buhay JE, Whiting MF, Crandall KA: Many species in one: DNA barcoding overestimates the number of species when nuclear mitochondrial pseudogenes are coamplified. Proc Natl Acad Sci USA 2008, 105(36):13486-13491.

12. Sallum MA, Foster PG, Dos Santos CL, Flores DC, Motoki MT, Bergo ES: Resurrection of two species from synonymy of Anopheles 
(Nyssorhynchus) strodei root, and characterization of a distinct morphological form from the strodei complex (Diptera: Culicidae). J Med Entomol 2010, 47(4):504-26.

13. Faran ME: Mosquito studies (Diptera: Culicidae) XXXIV. A revision of the Albimanus Section of the subgenus Nyssorhynchus of Anopheles. Contrib Am Entomol Inst 1980, 15:1-215.

14. Harbach RE: Anopheles Classification: Mosquito Taxonomic Inventory. http:// mosquito-taxonomic-inventory.info/ltemgtanopheles/temgt-classification.

15. Root F: Studies on Brazilian mosquitoes. I. The anophelines of the Nyssorhynchus group. Am J Hyg 1926, 6:684-717.

16. Unti O: Anofelinos do Vale do Paraiba. Nota III. Biologia do Anofeles [sic] (Nyssorhynchus) strodei Rooth, 1926 com a descricao d'uma variedade nova: Anofeles [sic] (Nyssorhynchus) strodei ramosi var. Ann Paulist Med Cir 1940, 40:489-505.

17. Unti O: Anofelinos do vale do Rio Paraiba, Anopheles (Nyssorhynchus) strodei Root 1926, com a descricao de tres variedades novas. Sao Paulo Serv Profil Mal Trab 1941, 33:3-18.

18. Galvão ALA: Observacoes sobre algumas species do subgenera Nyssorhynchus com especial referencia a morfologia dos ovos. Rev Biol Hyg 1938, 9:51-60.

19. Schereiber G, Guedes AS: Cytological aspects of the taxonomy of anophelines (subgenus Nyssorhynchus). Bull WHO 1961, 24:657-658.

20. Manguin S, Bangs M, Pothikasikorn J, Chareonviriyaphap T: Review on global co-transmission of human Plasmodium species and Wuchereria bancrofti by Anopheles mosquitoes. Infect Genet Evol 2010, 10:159-177.

21. Mitchell CJ, Monath TP, Sabattini MS, Cropp CB, Daffner JF, Calisher CH, Jakob WL, Christensena HA: Arbovirus investigations in Argentina, 19771980. II. Arthropod collections and virus isolations from Argentine Mosquitoes. Am J Trop Med Hyg 1985, 34:945-955.

22. Tadei WP, Dutary-Thatcher B: Malaria vectors in the Brazilian Amazon: Anopheles of the subgenus Nyssorhynchus. Rev Inst Med Trop Sao Paulo 2000, 42:87-94.

23. Oliveira-Ferreira J, Lourenço-de-Oliveira R, Teva A, Deane LM, Daniel-Ribeiro $C T$ : Natural malaria infections in anophelines in Rondonia State, Brazilian Amazon. Am J Trop Med Hyg 1990, 43:6-10.

24. Folmer O, Black M, Hoeh W, Lutz R, Vrijenhoek R: DNA primers for amplification of mitochondrial cytochrome c oxidase subunit I from diverse metazoan invertebrates. Mol Mar Biol Biotechnol 1994, 3:294-299.

25. Sallum MA, Marrelli MT, Nagaki SS, Laporta GZ, Dos Santos CL: Insight into Anopheles (Nyssorhynchus) (Diptera: Culicidae) species from Brazil. J Med Entomol 2008, 45:970-981.

26. Besansky NJ, Fahey GT: Utility of the white gene in estimating phylogenetic relationships among mosquitoes (Diptera: Culicidae). $\mathrm{Mol}$ Biol Evol 1997, 14:442-454.

27. Edgar RC: MUSCLE: multiple sequence alignment with high accuracy and high throughput. Nucleic Acids Res 2004, 32:1792-7.

28. Gouy M, Guindon S, Gascuel O: SeaView version 4: a multiplatform graphical user interface for sequence alignment and phylogenetic tree building. Mol Biol Evol 2010, 27:221-224.

29. Abascal F, Zardoya R, Telford MJ: TranslatorX: multiple alignment of nucleotide sequences guided by amino acid translations. Nucleic Acids Res 2010, 38:W7-13.

30. Keller A, Schleicher T, Schultz J, Müller T, Dandekar T, Wolf M: 5.8S-28S rRNA interaction and HMM-based ITS2 annotation. Gene 2009, 430:50-57.

31. Koetschan C, Förster F, Keller A, Schleicher T, Ruderisch B, Schwarz R, Müller T, Wolf M, Schultz J: The ITS2 Database III - sequences and structures for phylogeny. Nucleic Acids Res 2010, 38:D275-9.

32. Zuker M: Mfold web server for nucleic acid folding and hybridization prediction. Nucleic Acids Res 2003, 31(13):3406-15.

33. Seibel PN, Müller T, Dandekar T, Schultz J, Wolf M: 4SALE - A tool for synchronous RNA sequence and secondary structure alignment and editing. BMC Bioinformatics 2006, 7:498.

34. Seibel PN, Müller T, Dandekar T, Wolf M: Synchronous visual analysis and editing of RNA sequence and secondary structure alignments using 4SALE. BMC Res Notes 2008, 1:91.

35. Hall TA: BioEdit: a user-friendly biological sequence alignment editor and analyses program for Windows 95/98/NT Nucleic Acids. Symp Ser 1999, 41:95-98.

36. Darriba D, Taboada GL, Doallo R, Posada D: jModelTest 2: more models, new heuristics and parallel computing. Nat Methods 2012, 9:772.

37. Brown JM, Lemmon AR: The importance of data partitioning and the utility of Bayes factors in Bayesian phylogenetics. Syst Biol 2007, 56:643-655.

38. Ronquist F, Huelsenbeck JP: MRBAYES 3 Bayesian phylogenetic inference under mixed models. Bioinformatics 2003, 19:1572-1574.
39. Kumar S, Skjæveland A, Orr RJS, Enger P, Ruden T, Mevik BH, Burki F, Botnen A, Shalchian-Tabrizi K: AIR: A batch-oriented web program package for construction of supermatrices ready for phylogenomic analyses. BMC Bioinformatics 2009, 10:357.

40. Paradis E, Claude J, Strimmer K: APE: analyses of phylogenetics and evolution in R language. Bioinformatics 2004, 20:289-290.

41. Kimura $\mathrm{M}: \mathrm{A}$ simple method for estimating evolutionary rate of base substitutions through comparative studies of nucleotide sequences. J Mol Evol 1980, 16:111-120.

42. Tamura K, Peterson D, Peterson N, Stecher G, Nei M, Kumar S: MEGA5: Molecular Evolutionary Genetics Analysis using maximum likelihood, evolutionary distance, and maximum parsimony methods. Mol Biol Evol 2011, 28:2731-2739.

43. Brown SDJ, Collins RA, Boyer S, Lefort MC, Malumbres-Olarte J, Vink CJ, Cruickshank RH: SPIDER: an R package for the analysis of species identity and evolution, with particular reference to DNA barcoding. Mol Ecol Resour 2012, 12:562-565.

44. Meier R, Shiyang K, Vaidya G, Ng PKL: DNA barcoding and taxonomy in Diptera: a tale of high intraspecific variability and low identification success. Syst Biol 2006, 55:715-728.

45. Onyabe DY, Conn JE: Intragenomic heterogeneity of a ribosomal DNA spacer (ITS2) varies regionally in the Neotropical malaria vector Anopheles nuneztovari (Diptera: Culicidae). Insect Mol Biol 1999, 8:435-442.

46. Wilkerson RC, Reinert JF, Li C: Ribosomal DNA ITS2 sequences differentiate six species in the Anopheles crucians complex (Diptera: Culicidae). J Med Entomol 2004, 41:392-401.

47. Fairley TL, Kilpatrick CW, Conn JE: Intragenomic heterogeneity of internal transcribed spacer rDNA in Neotropical malaria vector, Anopheles aquasalis (Diptera: Culicidae). J Med Entomol 2005, 42:795-800.

48. Li C, Wilkerson RC: Intragenomic rDNA ITS2 variation in the Neotropical Anopheles (Nyssorhynchus) albitarsis complex (Diptera: Culicidae). J Hered 2006, 98:51-59.

49. Motoki MT, Bourke BP, Bergo ES, Silva AM, Sallum MAM: Systematic notes of Anopheles konderi and its first record in Paraná State, Brazil. J Am Mosa Control Assoc 2011, 27:191-200.

50. Galindo-Leal C, Câmara IG: Atlantic Forest Hotspot Status: an Overview. In The Atlantic Forest of South America: Biodiversity status, threats, and outlook. Edited by Galindo-Leal C, Câmara IG. Washington DC: Island Press; 2003:3-11.

51. Tabarelli M, Santos AMM: Uma breve descrição sobre a história natural dos Brejos Nordestinos. In Brejos de Altitude em Pernambuco e Paraíba, História Natural, Ecologia e Conservação. Edited by Porto KC, Cabral JJP, Tabarelli M. Brasília: M. Ministério do Meio Ambiente; 2004:17-24.

52. Foster PG, Bergo ES, Bourke BP, Oliveira TMP, Nagaki SS, Sant'Ana DC, Sallum MAM: Phylogenetic Analysis and DNA-based Species Confirmation in Anopheles (Nyssorhynchus). PLoS One 2013, 8(2):e54063.

53. Barrett RDH, Hebert PD: Identifying spiders through DNA barcodes. Can J Zool 2005, 83:481-491.

54. Hajibabaei M, Janzen DH, Burns JM, Hallwachs W, Hebert PD: DNA barcodes distinguish species of tropical Lepidoptera. Proc Natl Acad Sci USA 2006, 103:968-971

55. Elias M, Hill RI, Willmott KR, Dasmahapatra KK, Brower AVZ, Mallet J, Jiggins CD: Limited performance of DNA barcoding in a diverse community of tropical butterflies. Proc Biol Sci 2007, 274:2881-2889.

56. Meier R, Zhang G, Ali F: The use of mean instead of smallest interspecific distances exaggerates the size of the barcoding gap and leads to misidentification. Syst Biol 2008, 57:809-813

57. Virgilio M, Backeljau T, Nevado B, Meyer M: Comparative performances of DNA barcoding across insect orders. BMC Bioinformatics 2010, 11:206.

58. Funk DJ, Omland KE: Species-level paraphyly and polyphyly: frequency, causes, and consequences, with insights from animal mitochondrial DNA. Annu Rev Ecol Evol Syst 2003, 34:397-423.

59. Moritz C, Cicero C: DNA barcoding: promise and pitfalls. PLoS Biol 2004, 2(10):e354.

60. Bergsten J, Bilton DT, Fujisawa T, Elliott M, Monaghan MT, Balke M, Hendrich L, Geijer J, Herrmann J, Foster GN, Ribera I, Nilsson AN, Barraclough TG, Vogler AP: The effect of geographical scale of sampling on DNA barcoding. Syst Biol 2012, 61:851-869

61. Zhang A, He L, Crozier RH, Muster C, Zhu CD: Estimating sample sizes for DNA barcoding. Mol Phylogenet Evol 2010, 54:1035-1039.

doi:10.1186/1756-3305-6-111

Cite this article as: Bourke et al:: A multi-locus approach to barcoding in the Anopheles strodei subgroup (Diptera: Culicidae). Parasites \& Vectors 2013 6:111. 